\title{
WILL NOVEL CORONAVIRUS (COVID-19) PANDEMIC IMPACT AGRICULTURE, FOOD SECURITY AND ANIMAL SECTORS?
}

\author{
QUAL SERÁ O IMPACTO DA PANDEMIA DO NOVO CORONAVIRUS (COVID-19) \\ NA AGRICULTURA, SEGURANÇA ALIMENTAR E SETORES DE PRODUÇÃO \\ ANIMAL
}

\begin{abstract}
Mahmoud F. SELEIMAN ${ }^{1,2, *}$; Shaimaa SELIM ${ }^{3}$; Bushra Ahmed ALHAMMAD ${ }^{4}$; Basmah M. ALHARBI ${ }^{5}$; Fernando Cezar JULIATTI ${ }^{6 *}$

1. Plant Production Department, College of Food and Agriculture Sciences, King Saud University, Saudi Arabia; 2. Department of Crop Sciences, Faculty of Agriculture, Menoufia University, Egypt; 3. Department of Nutrition and Clinical Nutrition, Faculty of Veterinary Medicine, University of Menoufia, Shibin El-kom, Egypt; 4. Biology Department, College of Science and Humanity Studies, Prince Sattam Bin Abdulaziz University, Al Kharj, Kingdom of Saudi Arabia; 5. Department of Biology, Faculty of Science, University of Tabuk, Saudi Arabia; 6. Full Professor at University Federal of Uberlândia, MG, Brazil. Researcher 1D-CNPq. * Correspondence: mseleiman@ksu.edu.sa,mahmoud.seleiman@agr.menofia.edu.eg,juliatti@ufu.br
\end{abstract}

\begin{abstract}
The whole world is in a great danger due to the novel coronavirus (COVID-19) pandemic. In December 2019, the outbreak of COVID-19 took place in Wuhan, China and then rapidly spread all over the world. The current study provides potential expectations for the adverse impact of (COVID-19). The global infection affected globe on agricultural level such as agriculture, food supplies and animal production sectors. Till today, $29^{\text {th }}$ April 2020, there is no vaccine available for treating novel coronavirus, consequently, the outbreak resulted in closing borders and reducing production following social distancing measures. This short communication illustrates the possible implications and expected outcomes of the outbreak of coronavirus (COVID-19) on agricultural, food security, integrated pest management (IPM), animal productivity; and it predicts, as well, the possible adverse impacts on the economy worldwide. Brazil has one of the most important tropical agriculture in the world, being a leader in soybean production in the world. This chain impacts others such as meat and eggs. The impact of COVID-19 will be positive, encouraging the country to consolidate its leadership in the world market, stimulating exports, the machinery, inputs and fertilizers market, as well as generating employment and income in the country.
\end{abstract}

KEYWORDS: COVID-19. Agriculture. Food security. Integrated pest management (IPM). Integrated plant disease management (IPDM). Animal productivity. Economy.

\section{INTRODUCTION}

There were outbreaks of severe acute respiratory tract syndrome (SARS)-like virus over the last few months, starting from December 2019, when an unidentified etiology was first recorded in Wuhan, China (Wuhan Municipal Health Commission 2019). Following those outbreaks, a novel coronavirus 2 (SARS-CoV-2), previously known as 2019-nCoV, was recognized as the main causative virus in China, and then was identified later in different countries around the world (WORLD HEALTH ORGANIZATION; WHO 2020). Comparing the mortality levels of the pandemic virus to SARS (9.6\%) and Middle East respiratory syndrome $(35 \%)$, the present mortality level of SARS-CoV-2 is lower (5-7\%). However, SARS-CoV-2 is highly contagious and infectious from person to person, and one infected person can infect on average six persons (YAN et al. 2020). On $8^{\text {th }}$ of May 2020, COVID-19 coronavirus caused about $4.01 \mathrm{M}$ confirmed cases and 276216 deaths worldwide (WHO 2020). This means that death occurrence is about $6.9 \%$ of the total confirmed cases. On the other hand, the number of recovered cases on the same date was 1385184 cases, representing about $34.5 \%$ of the total positive confirmed cases. The case diagnoses were confirmed in more than 240 countries and territories, outside the mainland China. Reviewing the procedures and experiences of most affected countries (USA, China, Brazil, Spain, Italy, France and Germany) dealing with the pandemic SARS$\mathrm{CoV}-2$, it was proven that this virus can overcome the healthcare system of well-resourced countries. Due to the nonexistence of treating vaccines at the moment, interferences have focused on social distancing, tracing contact and quarantine.

Few information is conveyed about the possible evolution and causes of disease (WILDER- 
Will novel coronavirus...

SMITH et al. 2020). Currently, it is still unknown when the pandemic virus will reach its peak. Up till now, the main sources of the COVID-19 are still unidentified. However, the viral infection was triggered by human contacts with some kinds of local seafood and wildlife animals such as bats (WANG et al. 2020).

Some of the recently published studies reported the clinical symptoms of the infected patients with COVID-19 and estimated the spread of COVID-19 coronavirus (CHAN et al. 2020; HUANG et al. 2020). From the past pandemics, it has been reported that quarantines and logistic restrictions have an impact on human activities, economy and agriculture (BERMEJO 2004; HANASHIMA and TOMOBE 2012; BURGUI 2020; SICHE 2020). However, the impact of the COVID-19 pandemic on agriculture, food security and animal production are still uninvestigated. Therefore, the current investigation aims to determine whether there will be a direct impact of the COVID-19 pandemic on agriculture, food security and animal production and pose some critical questions on the implications for agronomy research.

\section{The impact of COVID-19 pandemic on agriculture and food security \\ The impact of COVID-19 on agronomic production}

Currently, farming systems face a wide range of economic, environmental and institutional challenges (MEUWISSEN et al. 2019). The most critical factors that would impact crop production and its quality, as a result of the COVID-19 pandemic, are soil fertility, availability of fertilizers, sowing and harvest dates, water availability, and pests or diseases. These factors in fact depend on agricultural machinery, laborers and international fertilizers and pesticides trade. Delaying the harvest process of forages can reduce the digestibility and crude protein (BUXTON 1996; SELEIMAN et al. 2017). As a result of the COVID-19 pandemic, labour shortage can delay some of the agricultural practices such as sowing, fertilizer application, irrigation, weed control and harvesting dates. Digital agricultural technologies and related tools can possibly represent viable alternatives to labour constraints as well as to minimize human contact during the pandemic of COVID-19. Using a set of digital and geospatial information technologies is the best hope to meet the challenge of sustainable agriculture and to enhance agricultural productivity through monitoring, evaluating and managing soil, climatic and genetic resources (BASSO and ANTLE
SELEIMAN, M. F. et al.

2020). Governments should innovate and collaborate to manage the international trade concerning agricultural inputs, in terms of fertilizers, pesticides, grains, animal products and other agri-food exports and imports to dampen the risks on the food system. The outbreak of COVID19 in China had an impact across the Chinese fertilizer sector, disturbing the movement of both fertilizers and raw materials in China. China is one of the most important producer and consumer for phosphates, sulphur and sulphuric acid (MARLOW 2020). The importing countries for synthetic fertilizers should partially increase the usage of bioand organic fertilizers as supplements with synthetic fertilizer. In following sections, the impact of COVID-19 on labour production, fertilizers, and some of important crops in relation to the international trades are discussed. It is also discussed in Brazil the impulse that will occur in the various production chains, including stimulating the biological, chemical and fertilizer control industry in the country to serve the various production chains, such as soybean, corn, sugar cane, citrus and coffee (Table 1 and Figure 4).

\section{Impact of COVID-19 on labour production}

It was reported by FAO (2020a, 2020b) that the developing countries are the most affected one by the consequences of (COVID-19). Nevertheless, statistics of COVID-19 show that the most affected countries currently are the most developed ones. At the moment, the highest confirmed cases with SARS-CoV-2 are found in USA followed by Spain, Italy, Germany, Brazil and France (Figure 1). Brazil occupies the sixth position in number of cases in the world, even surpassing China in numbers of deaths. The COVID-19 is causing losses in labour globally, and such effects are assumed to be far worse than the financial crisis of 2008-2009, particularly in the next three months (INTERNATIONAL LABOUR ORGANIZATION 2020). Most of the European countries have established border controls in order to curtail the outbreak of the COVID-19 (EURACITY 2020). In the developed countries such as Italy, there is lack of imported manpower than it is in the under-developed countries due to the further restrictions imposed by governmental measures to immigration, because of COVID-19. This would cause a decline in labour force availability, and adversely affect livelihoods and incomes. Nowadays, most of the infected countries with COVID-19 stated partial or full curfew as a result of contagion fear. Thus, farmers in different regions of the world will be in an impasse by the spring and/or summer seasons. Farmers and 
vegetable processors in Germany and Spain were warning from the border restrictions, because such restrictions can prevent thousands of East European seasonal workers from harvesting and planting farms in those countries. Consequently, this may reduce the production of fruits and veggies which consequently this leads to raising prices. To avoid the possibility of food shortage, the German Ministry of agriculture, seeks to attract additional 10,000 unemployed and students (EURACITY 2020), while the same Spanish Ministry seeks to attract an additional 80,000 person to labour on agricultural farms (INFO MIGRANTS 2020).

The COVID-19 pandemic inhaled the security of segments of the UK inhabitants. It increased unemployment and decreased work hours. In addition, the enforced self-isolation for several susceptible groups may cause an increment in UK food insecurity and diet-related health inequalities (POWER et al. 2020). Between $16^{\text {th }}-24^{\text {th }}$ March 2020, Farm Journal (https://www.agweb.com/farmjournal/magazine) conducted a survey to investigate the impact of COVID-19 on the businesses of 679 agricultural workers, farmers and ranchers from 43 different states of the USA. Almost $90 \%$ of respondents expected a negative impact on their business, while about $30 \%$ of them were worried to get infected with the novel coronavirus. In this investigation, ranchers and farmers were also concerned about the unexpected situation of the market as well as they were worried about the health of their labour force as well as their relatives.

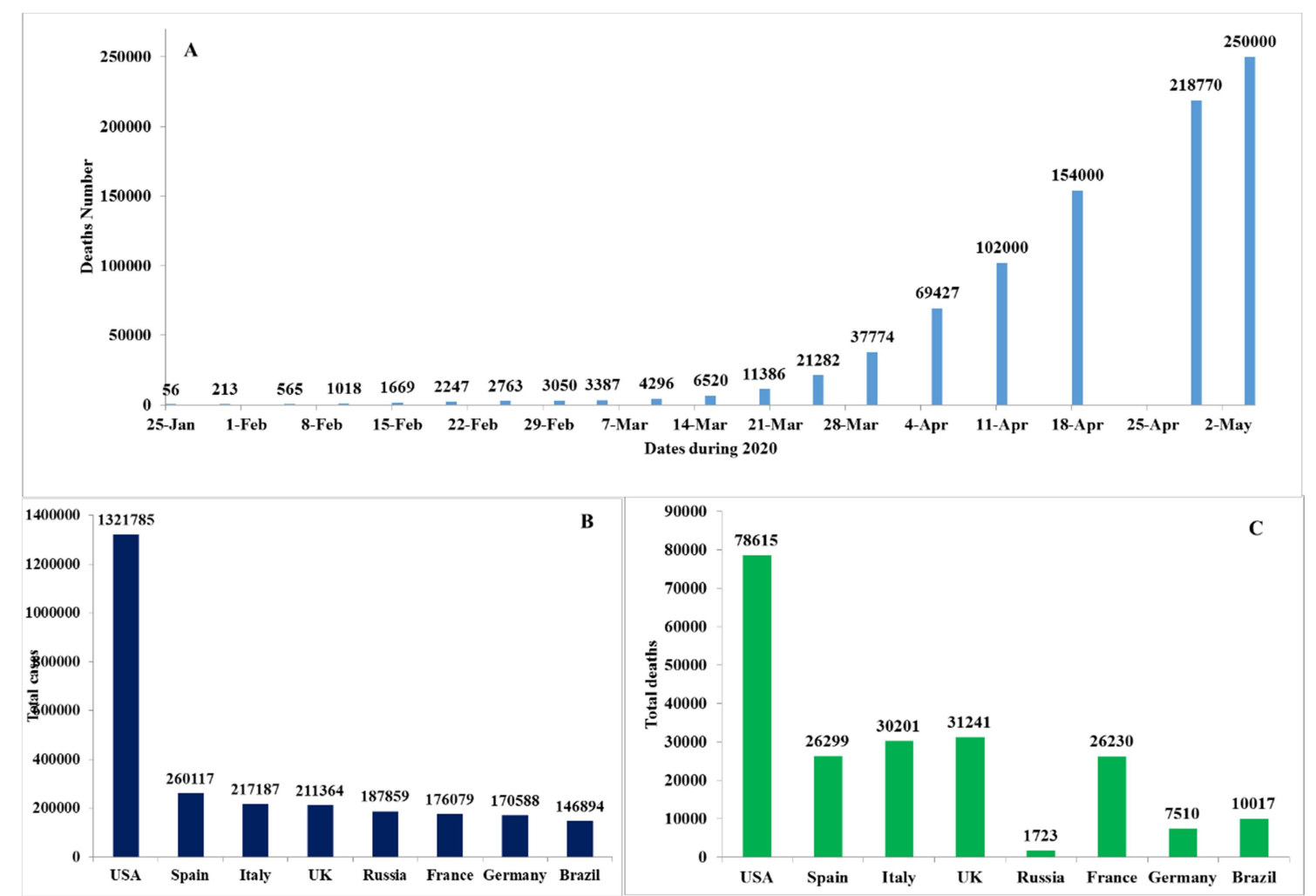

Figure 1. The total number of deaths worldwide (a), and total confirmed cases (b) and deaths (c) for the highest eight countries on $8^{\text {th }}$ April 2020 (Source: WHO 2020).

\section{The impact of COVID-19 on agriculture and food security}

While both the short-term and the long-term impact of (COVID-19) pandemic on food security is challenging, the potential risk could be predicted. In the last few months (January-March 2020), the global food supply has been sufficient and stable. For instance, cereals such as wheat and maize as well as legume crops supplies were sufficient (FAO 2020b). Nevertheless, the globe is going to face some challenges in shipping multiple food products such as vegetables and fruits from country to other countries during April-December 2020. Moreover, some countries such as USA, Russia, Argentina and Canada may reduce the export of cereals (i.e. maize and wheat) in the next few months due to the restrictions of transportation among countries (Table 1). The COVID-19 pandemic is having a positive impact on Brazilian Agribusiness, which is breaking records in different exports from other countries in the world, even with social isolation in the countryside that is different from the procedures 
Will novel coronavirus...

adopted in urban centers. In addition to shipment restrictions of foods, the behavior of workers can obstruct farmers from carrying out agricultural and food processing. Also, lack of fertilizers, pesticides, veterinary medicines as well as other inputs can adversely affect agricultural productivity (FAO
SELEIMAN, M. F. et al.

2020a). The COVID-19 pandemic is a hardchallenging test to the worldwide economy and international trade, for instance production and consumption are surmounted back all over the world (WORLD TRADE ORGANIZATION 2020).

Table 1. The import and export of soybeans, maize and wheat for the highest ten countries (Source: FAOSTAT 2020a).

\begin{tabular}{|c|c|c|c|c|c|}
\hline \multicolumn{6}{|c|}{ Import quantity (Mt) } \\
\hline Country & Soybeans & Country & Maize & Country & Wheat \\
\hline China & 98.10 & Mexico & 15.34 & Indonesia & 10.45 \\
\hline China, ML & 95.53 & Japan & 14.53 & Egypt & 10.16 \\
\hline Mexico & 4.34 & Korea & 9.32 & Algeria & 8.08 \\
\hline Netherlands & 3.85 & Egypt & 8.33 & Italy & 7.43 \\
\hline Spain & 3.40 & Viet Nam & 7.73 & Bangladesh & 6.87 \\
\hline Japan & 3.22 & Spain & 7.47 & Spain & 6.19 \\
\hline Germany & 3.02 & Iran & 7.32 & Brazil & 6.02 \\
\hline Thailand & 2.74 & China & 7.29 & China & 5.72 \\
\hline Indonesia & 2.54 & Italy & 5.41 & Japan & 5.71 \\
\hline Turkey & 2.34 & Netherlands & 5.20 & Nigeria & 5.69 \\
\hline \multicolumn{6}{|c|}{ Export quantity (Mt) } \\
\hline Country & Soybeans & Country & Maize & Country & Wheat \\
\hline Brazil & 68.15 & USA & 53.04 & Russian & 33.03 \\
\hline USA & 55.38 & Brazil & 29.27 & USA & 27.30 \\
\hline Argentina & 7.40 & Argentina & 23.71 & Canada & 22.06 \\
\hline Paraguay & 6.12 & Ukraine & 19.39 & Australia & 21.99 \\
\hline Canada & 4.66 & Russian & 5.18 & Ukraine & 17.31 \\
\hline Uruguay & 3.25 & France & 4.27 & France & 15.23 \\
\hline Ukraine & 2.87 & Romania & 3.77 & Argentina & 13.10 \\
\hline Netherlands & 0.96 & Hungary & 3.50 & Germany & 7.89 \\
\hline Russian & 0.52 & South Africa & 2.20 & Romania & 5.77 \\
\hline India & 0.29 & Paraguay & 1.89 & Kazakhstan & 4.26 \\
\hline
\end{tabular}

$\mathrm{ML}=$ mainland.

The N, P and $\mathrm{K}$ elements are the most important nutrients for plant growth and productivity (SELEIMAN 2014; KWON et al. 2019). The world production of nitrogen (N), phosphate $\left(\mathrm{P}_{2} \mathrm{O}_{5}\right)$ and potassium $\left(\mathrm{K}_{2} \mathrm{O}\right)$ fertilizers were $122.7,50.8$ and $40.4 \mathrm{Mt}$, while the agricultural uses of those fertilizers were 110.2, 48.6 and 38.7 Mt during 2016, respectively (Figure 2). Data in Table 2 show the top ten importers and exporters of the fertilizers worldwide. China is considered to be the highest exporter of $\mathrm{P}(5.32 \mathrm{Mt})$ and the second highest exporter of $\mathrm{N}$ fertilizers $(5.56 \mathrm{Mt})$, whereas Brazil is the largest importer for $\mathrm{N}(4.65 \mathrm{Mt})$ and $\mathrm{P}$ $(3.20 \mathrm{Mt})$, and is the second highest importer of $\mathrm{K}$ (6.03 Mt). Brazil (68.15 Mt) and the USA (55.38
Mt) supply the most soybean exports, and China accounts for more than $60 \%(98.10 \mathrm{Mt})$ of the world soybean import (GALE et al. 2019; FAOSTAT 2020b). Moreover, USA (53.04 Mt) and Brazil $(29.27 \mathrm{Mt})$ are the largest global exporters of maize, while Mexico (15.34 Mt) and Japan (14.53 Mt) are the largest maize importers (Table 1) (FAOSTAT 2020b). Soybeans and maize are considered to be the most essential sources of food, nutrition and bioenergy products worldwide, and they are crucial to food security (WU and GUCLU; SELEIMAN et al. 2013; SELEIMAN et al. 2017; GALE et al. 2019; FAOSTAT 2020b). Due to COVID-19 pandemic, the constraint of trade the Brazilian and American soybeans and maize would not be 
exported in large quantities, but it will stimulate domestic consumption and open new markets. That is why, soybeans and maize supply in many countries could be jeopardized. Furthermore, inadequate fertilizers triggered by COVID-19 logistic restrictions may cause unsatisfactory crop yields of soybeans, maize, sugar cane and coffee in Brazil. This means that Brazil and China may be the most affected countries as a result of borders closure and international constraint trade, in terms of fertilizers and crops industries. The positive point will be the generation of innovation startups in these countries, stimulating the generation of their own technologies and reducing the import of inputs. As they say in Brazil, Agribusiness does not stop and the country's vocation is food production. As it is said in Brazil, Agribusiness does not stop and the country's vocation is food and production (JULIATTI 2020). The situation is dissimilar in Egypt, although it is the second largest imported country of wheat (Table 1). The reason is that the Egyptian farmers are going to harvest their wheat crop at the end of April and beginning of May. Consequently, Egyptian market will have around 10 Mt of grain wheat, which can post the food insecurity more seven months. In addition, Egypt is one of the highest exporters for synthetic fertilizers worldwide (Table 2). In the short-term priority for the whole globe is to develop a vaccine for COVID19. However, researchers have to start thinking about more resilient food system that puts less stress on Earth and human health.

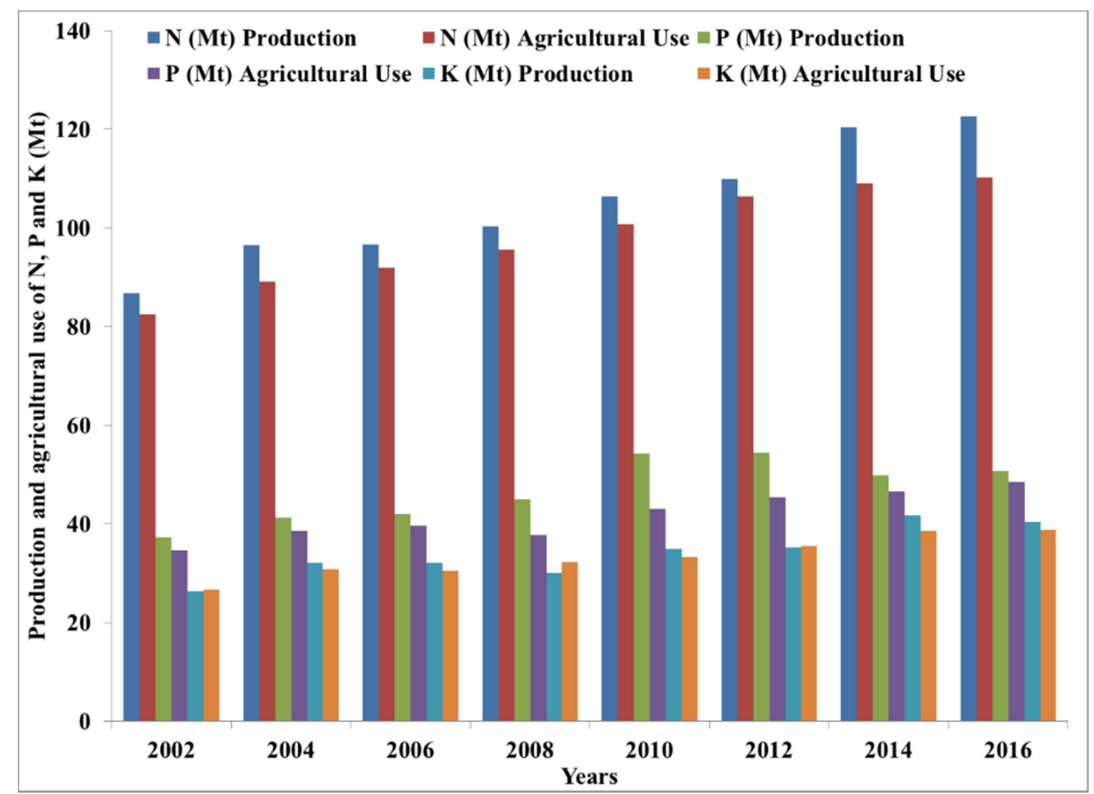

Figure 2. Total production and agricultural use of nitrogen $(\mathrm{N})$, phosphorus $(\mathrm{P})$ and potassium $(\mathrm{K})$ worldwide (FAOSTAT 2020b).

Table 2. The import and export of nitrogen, phosphate and potassium for the highest ten countries (Source: FAOSTAT 2020b).

\begin{tabular}{llllll}
\hline \multicolumn{7}{c}{ Import quantity $(\mathbf{M t})$} \\
\hline Country & Nitrogen $(\mathbf{N})$ & Country & Phosphate $\left(\mathbf{P}_{\mathbf{2}} \mathbf{O}_{\mathbf{5}}\right)$ & Country & Potassium $\left(\mathrm{K}_{2} \mathrm{O}\right)$ \\
\hline Brazil & 4.65 & Brazil & 3.20 & USA & 7.30 \\
India & 3.71 & India & 2.04 & Brazil & 6.03 \\
USA & 2.43 & USA & 1.12 & China & 4.99 \\
France & 2.15 & Indonesia & 0.96 & China, ML & 4.76 \\
Turkey & 1.75 & Pakistan & 0.80 & India & 2.75 \\
Thailand & 1.46 & Canada & 0.74 & Indonesia & 2.10 \\
Australia & 1.28 & Australia & 0.66 & Malaysia & 1.07 \\
Mexico & 1.25 & Argentina & 0.58 & Belgium & 1.01 \\
Germany & 1.23 & Ukraine & 0.53 & Viet Nam & 0.83 \\
Ukraine & 0.97 & Viet Nam & 0.52 & Netherlands & 0.70 \\
\hline
\end{tabular}

Export quantity (Mt) 


\begin{tabular}{llllll}
\hline Country & Nitrogen $(\mathrm{N})$ & Country & Phosphate $\left(\mathrm{P}_{2} \mathrm{O}_{5}\right)$ & Country & Potassium $\left(\mathrm{K}_{2} \mathrm{O}\right)$ \\
\hline Russian & 6.49 & China & 5.32 & Canada & 11.49 \\
China & 5.56 & China, ML & 5.31 & Russian & 7.50 \\
China, ML & 5.46 & Morocco & 3.20 & Belarus & 6.53 \\
Netherlands & 2.17 & Russian & 2.78 & Germany & 2.58 \\
Qatar & 2.08 & USA & 2.53 & Israel & 2.21 \\
USA & 2.07 & Saudi Arabia & 1.26 & Chile & 0.99 \\
Egypt & 1.66 & Belgium & 0.46 & Belgium & 0.51 \\
Belgium & 1.62 & Lithuania & 0.41 & Netherlands & 0.49 \\
Saudi Arabia & 1.59 & Israel & 0.38 & Spain & 0.49 \\
Oman & 1.51 & Mexico & 0.33 & China & 0.30 \\
\hline
\end{tabular}

$\mathrm{ML}=$ mainland.

\section{The impact of COVID-19 pandemic on animal sector}

Up till now, the sources and transmission routes of SARS-CoV-2 remain indefinite (ZHOU et al. 2020). The first infection was reported to be linked with a live animal market, including bats (96.2\% genome sequence identity) (ZHOU et al. 2020). However, the type of intermediate species that transmitted infection to humans remains unknown (CYRANOSKY 2020; GUO et al. 2020). Zhou et al. (2020) stated that direct contact with intermediate host animals or even consumption of wild animals is expected to be the main transmission route of SARS-CoV-2. In the USA, the first identified positive animal case of the novel coronavirus was reported in 27th March 2020 for a tiger with pneumonia at New York's Zoo (ASSOCIATED PRESS 2020). However, there is no any evidence that the companion animals can spread the coronavirus to humans, or these animals might be a source of infection (GOUMENOU et al. 2020). Till this moment, there is no certainty that the imported animals and their products can pose any threat of transmitting COVID-19 (SHAHIDI 2020). However, it is a must to cease consuming raw or undercooked animal products (SHADIDI 2020). Further investigations are needed to identify how animals can be affected by SARS-CoV-2 (WORLD ORGANIZATION FOR ANIMAL HEALTH 2020).

In most regions of the world, logistics restrictions and labour shortage due to the pandemic of COVID-19 may disrupt some of the agricultural market chains, restrict access to animal feeds and diminish capacity of slaughterhouses. These logistical plunges place some food chains in a high risk (FAO 2020b). Livestock farmers already suffer from shortage of labour in developed countries, concerning both farms and packing plants, since animals need to be fed daily and the production cycle is short for some animals; for instance, every day for dairy cows, few weeks for broilers and three months for pigs. Forecasts for economic growth have been cut for the year 2020, and the impact on consumers will reduce demands for animal protein (FOREIGN AGRICULTURAL SERVICE, FAS 2020). Closures of restaurants and food services, logistic restriction on tourism, as well as shipping disruptions are likely to impact livestock and poultry sectors, in terms of the supply and distribution chain. One of the suggested solutions is to invest in plant-based meat alternatives and cellular agriculture such as; growing animal tissue from stem cells to overcome food insecurity.

The last updates of global bovine meat production are 67.54 Mt (FAOSTAT 2018). The top three exporters of bovine meat are Brazil (1.86 Mt), India $(1.56 \mathrm{Mt})$ and Australia $(1.24 \mathrm{Mt})$, while the largest importers are the USA (1.11 Mt), Russia $(0.81 \mathrm{Mt})$, Japan $(0.68 \mathrm{Mt})$ and Italy $(0.50 \mathrm{Mt})$. By the end of 2018, the African Swine Fever caused about $50 \%$ loss of pigs in China. This led to a major shift in consumption from pork to beef and beef prices rose. As a result of global economic turmoil, the closures of hotels, restaurant and institutional sector, and restrictions on tourism triggered by COVID-19, the global beef production is likely to be adversely affected in 2020 due to the declines in beef demands in China, as well as in other major markets such as the USA (FAS 2020), and this will force the major producers to adapt their production plans (FAS 2020). On the other hand, chicken meat is expected to be more resilient when confronted with economic disturbance compared to red meat because of its low-price as an animal protein (FAS 2020).

Regarding global poultry meat production (FAOSTAT 2018), the top three exporters are USA (4.1 Mt), Brazil (3.9 Mt) and Netherlands (1.1 Mt), while the largest importers are China, Hong Kong 
SAR (1.2 Mt), Japan (1.1 Mt) and Saudi Arabia (0.9 Mt). In China, poultry farmers ceased selling broilers and eggs in markets due to a ban in live poultry movement. Many reports suggest that the market input of chickens was decreased by about $50 \%$ (FAO 2020a). In 2020, the global chicken meat production is expected to decline by $2 \%$ due to the gains in China fail to counterbalance lowered production predictions (FAS 2020). Nevertheless, world chicken meat production in 2020 is predicted to be increased by $1 \%$ because of the increased production in Brazil and the USA in exchange to declines in Europe, India and Thailand (FAS 2020). On the other hand, some companies will be in deficient in terms of breeding stock and hatching eggs (International Poultry Council, IPC 2020b). For instance, approximately $97 \%$ of eggs and $100 \%$ of chicks and parent flocks in Russian Turkey industry are imported from Europe and Canada (IPC 2020a). The import of feed ingredients such as soybean meal and feed additives as well as veterinary medications may be disrupted due to the COVID-19 pandemic. Thus, the costs of poultry and eggs are also expected to be significantly increased. Furthermore, livestock companies may face an increasing cost of feeds and medications triggered by the COVID-19 pandemic (IPC 2020a; 2020a).
Therefore, feed industry regulations, feed manufacturers and ingredient suppliers should prepare protocols to guarantee continuousness of production and nutrition supply while protecting workers.

Globally, fish is one of the most traded food possessions. Fish production was reported to provide up to $50 \%$ of animal protein in some developed countries (FAO 2020a). The total world fisheries and aquatic production and human consumption increased from 154 to $130 \mathrm{Tg}$ in 2011 to 171 and $151 \mathrm{Tg}$ in 2016, respectively (Figure 3). According to FAOSTAT (2018), the largest exporting countries for aquaculture are China (112.8 $\mathrm{Tg}$ ), Thailand $(25.2 \mathrm{Tg}$ ), and Indonesia $(23.8 \mathrm{Mg}$ ton) while the most importing countries are Japan (47 Mg ton), Netherlands (39.8 Mg ton), Italy (28.7 $\mathrm{Mg}$ ton) and USA (27.2 Tg). The implications of COVID-19 on fishing and aquaculture sectors are quite complex. Concerning wild-capture fisheries and aquaculture, the inability of fishing vessels to work, due to collapse of market, limited workforce, border closures, as well as sanitary measures, can create a domino effect on the supply of fish products and cause significant market changes, disturbing prices (FAO 2020a). This may lead some countries to adjust their source of protein intake.

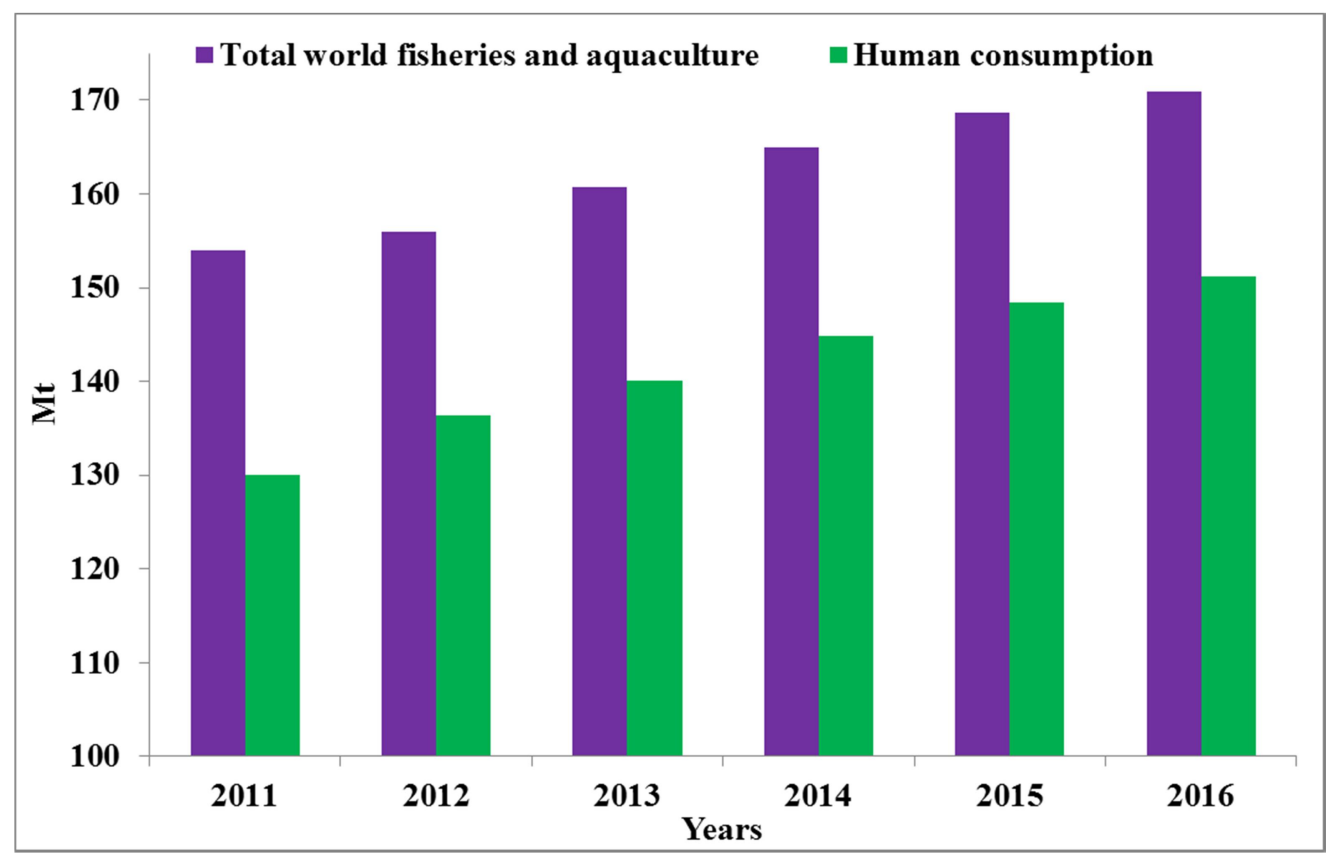

Figure 3. World fisheries and aquaculture production and human consumption (Sources: FAOSTAT 2018).

There is a possibility of a dramatic reduction in animal protein intake due to the concern regarding potential COVID-19 persistence on raw foods originate from animals, including raw fish products. Nevertheless, there is no current evidence that the transmission of SARS-CoV-2 through raw food can occur (GOUMENOU et al. 2020; SHAHIDI 2020; WHO 2020). Fish and shellfish markets are already severely affected because of a dramatic drop in fish prices due to 
Will novel coronavirus...

logistical difficulties and travel restrictions triggered by COVID-19. The aquaculture industry currently deals with a common disruption of demand causing dire penalties for the supply chain of fresh fish. Therefore, frozen seafood companies are facing strong demand. These companies may encounter some problems soon to reconstruct their stocks, if logistics restrictions are constrained (WHO 2020). In addition, seasonal fishing is probably obstructed by restrictions in Italy and France, predominantly because of closures in the restauration sector (National Federation of Fishermen's Organizations, NFFO 2020). There are worries regarding how fish production units will progress with fewer domestic buyers for aquatic products and affected workforce (NFFO 2020 ).The economic and financial disruptions inflicted by COVID-19 are certainly putting the U.S. economy, including the ag industry, at serious risk. However, the true effect of this impact remains unknown and that is what creates so much uncertainty and panic around the globe.There are at least three realistic scenarios for the U.S. agriculture industry amid coronavirus panic:Optimistic V-shape case. After a rapid decline, the markets revive quickly and show new growth due to accumulated potential and "relieved" demand;Neutral U-shape. Slow surging and slow restoration of the market's normal performance;Pessimistic L-shape. Rapid decline and stagnation, possible in case of global panic and pandemic. The influence of the virus can and must be contained in order to prevent the world economy from another major financial crisis. For that,
SELEIMAN, M. F. et al.

governments need to act quickly and methodically while communicating their efforts and actions. The consequences will begin to hit full force in a matter of weeks and could last for months if not years (SAKAL, 2020).

In phytosanitary management in Brazil, COVID-19 will positively impact the various production chains such as: soy, corn, coffee, cane, citrus, cotton, rubber, wheat and vegetables. The techniques will be refined as the biological, chemical and cultural management. Startups will be created taking the country to reach unimaginable levels in the creation of new markets and new partnerships. Certainly, the last grain harvest of 251 Mt will be surpassed. It will also increase the appreciation of the professional who works in agriculture. The offer of services will be increased, as well as the improvement of the infrastructure in the country and, consequently, the growth of agribusiness. The agricultural pesticide industry in Brazil occupies a prominent place in a market of almost 10 Billion dollars (10 US \$ Bi). Registration processes at government agencies must be accelerated to improve the availability of sustainable assets and molecules in phytosanitary defense (JULIATTI, 2020). The figure 4 shows the impact of Coronavirus in the mains chains from agriculture until 4-April-2020. The impact was positive and stimulates the growth of Brazilian agribusiness. Technology such as digitalization in the field, the use of drones are transforming the entire Brazilian agribusiness and the improvement of technicians.

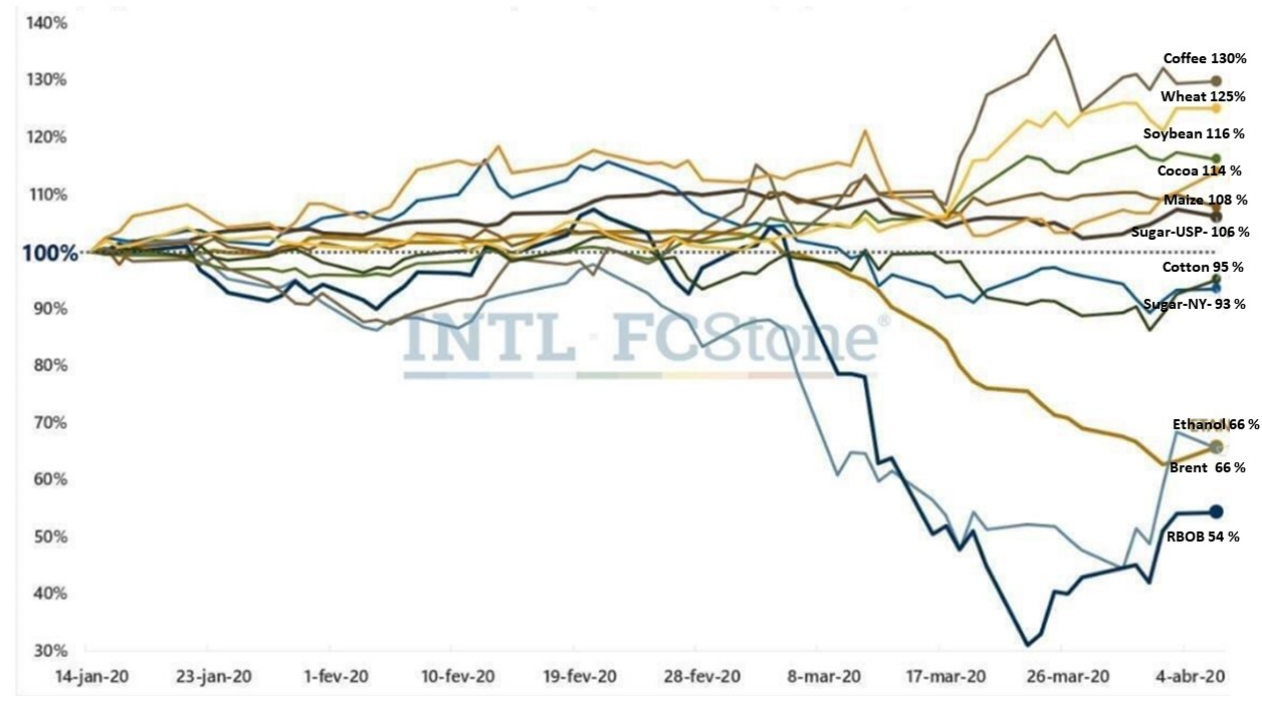

Figure 4. Impacts of Coronavirus in the main Agriculture chains (commodities) in Brazil. 


\section{CONCLUSION}

As a result of COVID-19 pandemic, agriculture in terms of crop production, food and animal production sectors will be adversely affected. Consequently, food crises are expected. The impact of COVID-19 on food security depends on the availability of different food items. Additionally, it depends on the estimated time frame to contain the COVID-19 pandemic. Closures of restaurants and food services, logistic restriction on tourism, as well as shipping disruptions are likely to impact livestock and poultry sectors, in terms of supply and distribution chain.

Digital agricultural technologies can offer alternative options to minimize human contact and labour constraints during the pandemic of COVID19. In addition, governments should collaborate to maintain the international trade in terms of fertilizers, pesticides, grains and other agri-food exports and imports. Furthermore, the expected adverse impact of COVID-19 on food security can be minimized through enhancing local productions and short food supply chains.

Technology such as digitalization in the field, the use of drones are transforming the entire Brazilian agribusiness and the improvement of technicians in many chains of the Brazilian agribusiness, such as the integrated pest management and crop management. Technologies and solutions for supplying the food production sector are being implemented such as biological control and precision agriculture in new Brazilian companies.

\section{ACKNOWLEDGMENTS}

The authors thank their specialist colleagues (Dr. Khaled Abass; Dr. Marwa Abolfotouh; Dr. Nesreen Elshaer) for the English language editing.

RESUMO: O mundo inteiro está em grande perigo e conflitos diversos devido à nova pandemia de coronavírus (COVID-19). Em dezembro de 2019, o surto de COVID-19 ocorreu em Wuhan, China e depois se espalhou rapidamente por todo o mundo. O presente estudo fornece expectativas em potencial para o impacto adverso do (COVID-19). A infecção global afetou o mundo no nível agrícola, como os setores de suprimento de alimentos e produção animal. Não há vacina disponível para o tratamento de novos coronavírus, consequentemente, o surto resultou no fechamento de fronteiras e na redução da produção seguindo medidas de distanciamento social. Esta breve comunicação ilustra as possíveis implicações e resultados esperados do surto de coronavírus (COVID-19) na agricultura, segurança alimentar, manejo fitossanitário e produtividade animal. O Brasil tem uma das mais importantes Agriculturas tropicais do mundo. Sendo líder na produção de soja no globo terrestre. Essa cadeia impacta outras como as de carnes e ovos. O impacto da COVID-19 será positivo estimulando o País a consolidar sua liderança no mercado mundial, estimulando as exportações, mercado de máquinas, insumos e fertilizantes, bem como gerrar emprego e renda no País. Prevê também, os possíveis impactos adversos na economia em todo o mundo.

PALAVRAS-CHAVE: COVID-19. agricultura. alimento seguro. manejo integrado de doenças e pragas (MIDP E MID). manejo integrado de doenças de plantas (IPDM). produtividade animal. economia.

\section{REFERENCES}

ASSOCIATED PRESS, 2020. Tiger at NYC's Bronx Zoo tests positive for COVID-19, believed to be 1st animal infection in U.S. Available from: https://ktla.com/author/associated-press/. [Accessed date: 16.04.2020].

BASSO B., ANTLE J., 2020. Digital agriculture to design sustainable agricultural systems. Nature sustainability 3: 254-256. https://doi.org/10.1038/s41893-020-0510-0

BERMEJO, A. 2004. HIV/AIDS in Africa: International responses to the pandemic. New Economy 11(3): 164169.BURGUI, D. 2020. Coronavirus: How action against hunger is responding to the pandemic. Available in:https://www.actionagainsthunger.org/story/coronavirus-how-action-against-hunger-respondingpandemic. [Accessed date: 18.04.2020]. https://doi.org/10.1111/j.1468-0041.2004.00357.x 
BUXTON D. R., 1996. Quality-related characteristics of forages as influenced by plant environment and agronomic factors. Anim. Feed Sci. Technol. 59: 37-49. https://doi.org/10.1016/0377-8401(95)00885-3

CHAN J. F., YUAN S., KOK K.H., TO. K.K., CHU H., YANG J., XING F., LIU J., YIP C.C., POON R. W., et al., 2020. A familial cluster of pneumonia associated with the 2019 novel coronavirus indicating person-toperson transmission: A study of a family cluster. Lancet. 395:514-523. https://doi.org/10.1016/S01406736(20)30154-9

CYRANOSKI D., 2020. Mystery deepens over animal source of coronavirus. Nature. 579:18-19.EURACITY, 2020. Germany to relax coronavirus border controls for farm workers. Available From:

https://www.euractiv.com/section/agriculture-food/news/germany-to-relax-coronavirus-border-controls-forfarm-workers/. [Accessed date: 16.04.2020]. https://doi.org/10.1038/d41586-020-00548-w

FAO, 2020a. Coronavirus disease 2019 (COVID-19) - Addressing the impacts of COVID-19 in food crises. Available from: htpp://www.fao.org/emergencies//appeals/detail/en/c/1270012/. [Accessed date: 15.04.2020]

FAO, 2020b.Novel Coronavirus (COVID-19). Available from: http://www.fao.org/2019-ncov/highlights/en/. [Accessed date: 08.04.2020].

FAOSTAT, 2020a. Crops and livestock products.FAO Statistical Databases \& Data-Sets. Available from: http://www.fao.org/faostat/en/\#data/TP. [Accessed date: 04.04.2020].

FAOSTAT, 2020b. Fertilizers. FAO Statistical Databases \& Data-Sets. Available from: http://www.fao.org/faostat/en/\#data/RFB. [Accessed date: 04.04.2020]

FAOSTAT, 2018. The State of world fisheries and aquaculture 2018 - Meeting the sustainable development goals. Rome. Licence: CC BY-NC-SA 3.0 IGO. Available from: http://www.fao.org/state-of-fisheriesaquaculture. [Accessed date: 13.04.2020].

HANASHIMA, M.; TOMOBE, K. 2012. Urbanization, industrialization, and mortality in modern Japan: A spatiotemporal perspective. Annals of GIS 18(1): 57-70. https://doi.org/10.1080/19475683.2011.647078

HUANG C., WANG Y., LI X., REN L., ZHAO J., HU Y., ZHANG L., FAN G., XU J., GU X. et al., 2020. Clinical features of patients infected with 2019 novel coronavirus in Wuhan, China. Lancet 395:497-506. https://doi.org/10.1016/S0140-6736(20)30183-5

FOREIGN AGRICULTURAL SERVICE (FAS), 2020. Livestock and Poultry: World markets and trade: COVID-19 upends global protein markets. Available from: https://apps.fas.usda.gov/psdonline/circulars/livestock_poultry.pdf. [Accessed date: 05.04.2020].

GALE F., VALDES C., ASH M., 2019. Interdependence of China, United States, and Brazil in soybean trade. A Report from the economic research service. Available from: https://www.ers.usda.gov/webdocs/publications/93390/ocs-19f-01.pdf?v=4048.3. [Accessed date: 16.03.2020].

GOUMENOU M., DEMETRIOS A.S., ARISTIDIS, T., 2020. "Possibility of Transmission through Dogs Being a Contributing Factor to the Extreme Covid 19 Outbreak in North Italy. Mol. Med. Report. Available from: https://doi.org/10.3892/mmr.2020.11037

GUO Y.R., CAO Q.D., HONG Z.S., et al., 2020. The origin, transmission and clinical therapies on coronavirus disease 2019 (coVid-19) outbreak - an update on the status. Mil. Med. Res. 7:11.

https://doi.org/10.1186/s40779-020-00240-0

INTERNATIONAL LABOUR ORGANIZATION, 2020. COVID-19: Stimulating the economy and labour demand. Available from: https://www.ilo.org/global/about-the-ilo/newsroom/news/WCMS_740893/lang-en/index.htm. [Accessed date: 11.04.2020]. 
INFO MIGRANTES, 2020. Spain to hire foreign workers to cover agriculture shortfall. Available from: https://www.infomigrants.net/en/post/23946/spain-to-hire-foreign-workers-to-cover-agriculture-shortfall. [Accessed date: 10.04.2020].

INTERNATIONAL POULTRY COUNCIL (IPC), 2020a. Coronavirus could disrupt poultry production. Available from: https:/www.poultryworld.net/Meat/Articles/2020/4/Coronavirus-could-disrupt-poultryproduction-563092E/.[Accessed date: 12.04.2020].

INTERNATIONAL POULTRY COUNCIL (IPC), 2020b. Covid-19: Impact on the global poultry sector. Available from: https://www.internationalpoultrycouncil.com/.[Accessed date: 13.04.2020].

JULIATTI, F.C. 2020. Projeções de manejo fitossanitário para 2021- Oportunidades de negócios e agregação de valor no Agro. https:/www.youtube.com/watch?v=9mfD-zA5HyU\&t=287s.

KWON S., KIM H., ROY S.K. et al., 2019. Effects of nitrogen, phosphorus and potassium fertilizers on growth characteristics of two species of Bellflower (Platycodon grandiflorum). J. Crop Sci. Biotechnol. 22:481-487. https://doi.org/10.1007/s12892-019-0277-0

MARLOW S., 2020. COVID-19: Effects on the Fertilizer Industry. HIS Markit; Agribusiness Research \& Analysis. Available in: https://ihsmarkit.com/research-analysis/report-covid19-effects-on-the-fertilizerindustry.html. [Accessed date: 21.04.2020].

MEUWISSEN M.P.M., FEINDT P.H., SPIEGEL A., TERMEER C.J.A.M., MATHIJS E., et al., 2019. A framework to assess the resilience of farming systems. Agric. Syst. 176: 102656.

https://doi.org/10.1016/j.agsy.2019.102656

NATIONAL FEDERATION OF FISHERMEN'S ORGANIZATIONS (NFFO), 2020. Impact of Coronavirus on Fishing. Available from: https://nffo.org.uk/news/impact-of-coronavirus-on-fishing.html. [Accessed date: 12.04.2020].

POWER M., DOHERTY B., PYBUS K., PICKETT K., 2020. How Covid-19 has exposed inequalities in the UK food system: The case of UK food and poverty [version 1; peer review: 2 approved with reservations]. Emerald Open Res. 2(11):1-16. Available from: https://doi.org/10.35241/emeraldopenres.13539.1. [Accessed date: 12.04.2020].

SAKAI, A. 2020. The coronavirus pandemic: Is U.S. agriculture in danger. EOS Crop Monitoring, April, 3. https://www.agdaily.com/insights/coronavirus-is-u-s-agriculture-in.-

SELEIMAN M.F., SELIM S., JAAKKOLA S., MÄKELÄ P., 2017. Chemical composition and in vitro digestibility of whole-crop maize fertilized with synthetic fertilizer or digestate and harvested at two maturity stages in boreal growing conditions. Agric. Food Sci. 26:47-55. https://doi.org/10.23986/afsci.60068

SELEIMAN M.F., 2014. Towards sustainable intensification of feedstock production with nutrient cycling. 71 p. Doctoral Dissertation. Department of Agricultural Sciences, Publication no 22, University of Helsinki, Finland. Available from:

https://helda.helsinki.fi/bitstream/handle/10138/42898/Mahmoud\%20Seleiman_PhD\%20Thesis.pdf?sequence= 1. [Accessed date: 12.03.2020].

SELEIMAN M.F., SANTANEN A., JAAKKOLA S., EKHOLM P., HARTIKAINEM H., STODDARD F.L., MÄKELÄ P.S.A., 2013. Biomass yield and quality of bioenergy crops grown with synthetic and organic fertilizers. Biomass Bioenergy. 59:477-485. https://doi.org/10.1016/j.biombioe.2013.07.021

SICHE, R., 2020. What is the impact of COVID-19 disease on agriculture? Scientia Agropecuaria 11(1): 3-6. https://doi.org/10.17268/sci.agropecu.2020.01.00 
SHAHIDI F.., 2020. Does COVID-19 Affect Food Safety and Security?. Journal of Food Bioactives, 9. Available from: https://doi.org/10.31665/JFB.2020.9212. [Accessed date: 10.04.2020].

WANG W., TANG J., WEI F., 2020. Updated understanding of the outbreak of 2019 novel coronavirus (2019ncov) in Wuhan, China. J. Med. Virol. 92(4):441-447. https://doi.org/10.1002/jmv.25689

WHO (World Health Organization), 2020. Coronavirus disease (COVID-19) Pandemic. Available from: https://www.who.int/. [Accessed date: 01.04.2020].

WILDER-SMITH A., CHIEW C.J., LEE V.J., 2020. Can we contain the covid-19 outbreak with the same measures as for SARS? Lancet. In Press. Available from: https://doi.org/10.1016/S1473-3099(20)30129-8. [Accessed date: 10.04.2020].

WORLD ORGANIZATION FOR ANIMAL HELATH, 2020. Questions and answers on the 2019 coronavirus disease (COVID-19). Available from: https://www.

oie.int/en/scientific-expertise/specific-information-and-recommen-

dations/questions-and-answers-on-2019novel-coronavirus/. [Accessed date: 10.04.2020].

WORLD TRADE ORGANIZATION, 2020. COVID-19 and world trade. Available from: https://www.wto.org/english/tratop_e/covid19_e/covid19_e.htm. [Accessed date: 11.04.2020].

WU F., GUCLU H., 2013. Global maize trade and food security: implications from a social network model. Risk Anal. 33(12):2168-2178.WUHAN MUNICIPAL HEALTH COMMISSION, 2019. Wuhan Municipal Health Commission's Briefing on the Pneumonia Epidemic Situation. Available from: http://wjw.wuhan.gov.cn/front/web/showDetail/2019123108989. [Accessed date: 16.02.2020]. https://doi.org/10.1111/risa.12064

YAN Y., SHIN W., PANG Y.X., MENG Y., LAI J., YOU C., ZHAO H., LESTER E., WU T., PANG C.H., 2020. The First 75 Days of Novel Coronavirus (SARS-CoV-2) Outbreak: Recent Advances, Prevention, and Treatment. Int. J. Environ. Res. Public Health. 17:2323. https://doi.org/10.3390/ijerph17072323

ZHOU P., YANG X.1., WANG X.G., et al., 2020. A pneumonia outbreak associated with a new coronavirus of probable bat origin. Nature 579: 270-273. 